\title{
KELOMPOK TERNAK SAPI POTONG
}

\section{GROUPS BROKEN CUTTING COW}

\author{
Muhammad Firdaus ${ }^{1}$ dan Dwi Indarti ${ }^{2}$ \\ ${ }^{12}$ Dosen STIE Mandala, Jember \\ Email: muhammadfirdaus2011@gmail.com dan indartidwi@gmail.com
}

\begin{abstract}
ABSTRAK
Pengabdian ini berjudul "PKM Kelompok Ternak Sapi Potong di Desa Tanjung Rejo, Kecamatan Wuluhan, Kabupaten Jember, Provinsi Jawa Timur". Permasalahan utama berkaitan dengan ketersediaan pakan yang dihadapi usaha ternak sapi potong ini adalah: (1) menjaga ketersediaan pakan hijauan, khususnya di musim penghujan, (2) membuat pakan dari bahan di sekitar mereka. Berdasar permasalahan tersebut, maka solusi yang ditawarkan adalah penyuluhan dan atau praktek tentang: (1) pemanfaatan sela-sela pekarangan/sawah yang dimiliki dengan menanam rumput terutama rumput gajah, (2) pembuatan fermentasi jerami untuk mengganti pakan hijauan, (3) pembuatan pakan konsentrat. Metode yang dipakai dalam pencapaian tujuan tersebut adalah : (1) Metode Pendekatan Personal kepada ketua dan anggota kelompok, (2) Metode Penyuluhan, dan (3) Metode Pendekatan Praktek. Hasilnya, Tim Pelaksana Pengabdian Kemitraan Masyarakat (PKM) telah melakukan penyuluhan dan praktek sehingga peternak mampu: (1) memanfaatkan di sela-sela pekarangan/sawah yang dimiliki dengan menanam rumput terutama rumput gajah, (2) pembuatan fermentasi jerami untuk mengganti pakan hijauan, (3) membuat pakan konsentrat dengan menggunakan bahan baku yang ada di sekitar mereka dengan penambahan probiotik, untuk menghasilkan pakan ternak berkualitas tinggi.
\end{abstract}

Kata Kunci: PKM, Ternak, Sapi Potong, Pakan

\begin{abstract}
This service is entitled "PKM for Beef Cattle Group in Tanjung Rejo Village, Wuluhan District, Jember Regency, East Java Province". The main problems related to the availability of food faced by beef cattle business are: (1) maintaining the availability of forage feed, especially in the rainy season, (2) making feed from ingredients around them. Based on these problems, the solutions offered are counseling and / or practice on: (1) utilization of the sidelines / fields owned by planting grass, especially elephant grass, (2) making straw fermentation to replace forage feed, (3) making feed concentrate. The methods used in achieving these objectives are: (1) Personal Approach Method to the chairman and group members, (2) Extension Method, and (3) Practice Approach Method. As a result, the Community Partnership Service Team (PKM) has conducted counseling and practice so that farmers are able to: (1) utilize between the fields / fields owned by planting grass, especially elephant grass, (2) making straw fermentation to replace forage feed, (3) making concentrate feed using raw materials around them with the addition of probiotics, to produce highquality animal feed.
\end{abstract}

Keywords: PKM, Livestock, Beef Cattle, Feed 


\section{PENDAHULUAN}

\section{Analisis Situasi}

Kebutuhan daging sapi di dalam negeri belum mampu dicukupi oleh peternak di Indonesia sebagai produsen lokal. Kondisi ini menyebabkan Indonesia melakukan impor daging sapi maupun ternak sapi, selain itu banyak terjadi pemotongan ternak produktif untuk memenuhi permintaan daging sapi, yang akhirnya dapat menyebabkan populasi ternak sapi semakin menurun. Oleh karena itu peningkatan populasi sapi potong perlu dilakukan (Budiharjo, dkk, 2011).

Usaha ternak sapi potong di Indonesia sebagian besar masih merupakan usaha peternakan rakyat yang dipelihara secara tradisional bersama tanaman pangan (Suryana, 2009). Pemeliharaannya dapat dibedakan menjadi dua bagian yaitu pemeliharaan sebagai pembibitan dan penggemukkan (Sudarmono dan Bambang, 2016). Widiyaningrum (2005), menyatakan bahwa ciri-ciri dari pemeliharaan dengan pola tradisional yaitu kandang dekat bahkan menyatu dengan rumah dan produktivitas rendah. Sudarmono dan Sugeng (2008), menyatakan ternak potong merupakan salah satu penghasil daging yang memiliki nilai ekonomi tinggi dan penting artinya di dalam kehidupan masyarakat. Keberhasilan usaha sapi potong sangat tergantung pada pemenuhan nutrisi dan kesehatan ternak. Pakan merupakan biaya produksi yang terbesar dalam usaha peternakan yaitu sekitar 60-70\% dari biaya produksi (Koestanty, dkk, 2014). Sehingga penyusunan ransum sapi tidak hanya harus mencukupi kebutuhan nutrisi tetapi juga harus secara ekonomis menguntungkan.

Kabupaten Jember yang berpenduduk $\pm 2,5$ juta (BPS Jember, 2017) dan berpendapatan cukup tinggi memiliki potensi untuk pengembangan sapi potong. Namun tampak bahwa petani masih memelihara sapi secara tradisional. Ternak sapi masih difungsikan sebagai tabungan atau merupakan pekerjaan sampingan. Para petani masih sangat minim informasi tentang cara beternak sapi yang baik dan benar, sehingga sapi hasil budidayanya terlihat tidak/kurang memiliki postur yang bagus dan produktivitasnya rendah, khususnya pertambahan bobot daging per hari. Muaranya adalah kesalahan dalam pemilihan bakalan sapi potong yang unggul dan masalah pakan serta kandang.

Situasi dan kondisi yang sama terjadi juga terjadi di Desa Tanjungrejo, Kecamatan Wuluhan, Kabupaten Jember, Provinsi Jawa Timur. Penduduk di Desa Tanjungrejo, sebagaimana penduduk desa lainnya, masih mengandalkan pertanian sebagai mata 
pencaharian utama. Selain itu, mereka juga beternak sapi sebagai mata pencaharian sampingan, untuk menambah pendapatan. Dua kelompok yang mengusahakan pemeliharaan sapi potong untuk tujuan penggemukan (feedloot) adalah Kelompok Ternak "Unggul” dan Kelompok Ternak "Karya Makmur".

Peternak sapi potong mengandalkan pakan dari rumput. Padahal di musim kemarau ketersediaan pakan hijauan ini relatif langka. Mereka berusaha mencarinya sampai ke tempat-tempat yang cukup jauh atau mendatangkan hijauan dari luar daerah dengan harga yang tinggi. Atau mereka bisa membeli hijauan dari jagung, di mana biaya per ekor sapi potong yang dibutuhkan adalah \pm Rp30.000,- per hari. Jika dibandingkan dengan kenaikan bobot sapi per hari $( \pm 0,5 \mathrm{~kg} / \mathrm{hari})$, maka keuntungannya sangat tipis. Mereka belum mampu membuat pakan sendiri, di mana bahan baku utamanya berasal dari lingkungan sekitar yang melimpah.

Khusus untuk masalah pakan, maka perlu adanya penyuluhan dan pendampingan pembuatan pakan komplet (completed feed). Menurut Suwignyo, dkk (2016) pakan komplet untuk sapi dapat menggunakan bahan baku limbah dengan penambahan probiotik, untuk menghasilkan pakan ternak berkualitas tinggi. Diharapkan pakan lengkap tersebut mampu membantu memecahkan masalah para peternak yaitu penyediaan pakan bermutu dengan harga terjangkau, mudah pemberiannya, dan mudah pembuatannya. Aplikasi teknologi pakan komplit berbasis sumberdaya lokal ini dapat dapat menekan biaya pakan dan meningkatkan produktivitas sapi potong.

\section{Permasalahan Mitra}

Berdasar hasil kunjungan dan diskusi dengan kelompok mitra, maka disepakati beberapa persoalan yang berkaitan dengan ketersediaan pakan dan menjadi prioritas untuk diselesaikan selama pelaksanaan program PKM berlangsung, yakni:

1. Bagaimana setiap anggota kelompok mitra mampu mengatasi kekurangan hijauan untuk pakan, khususnya di musim kemarau.

2. Bagaimana setiap anggota kelompok mitra mampu membuat pakan yang baik dari bahan-bahan yang melimpah yang ada di sekitar kelompok mitra. 


\section{SOLUSI YANG DITAWARKAN}

Adapun solusi yang ditawarkan dan jenis luaran yang ditawarkan dari kegiatan PKM ini adalah:

1. Penyuluhan dan praktek mengatasi kekurangan hijauan dengan menanam rumput, terutama rumput gajah.

2. Penyuluhan dan praktek mengatasi kekurangan hijauan dengan fermentasi jerami.

3. Penyuluhan dan praktek pembuatan pakan konsentrat.

\section{METODE PELAKSANAAN}

\section{Langkah-langkah dalam Melaksanakan Solusi dari Permasalahan Mitra}

Langkah-langkah dalam melaksanakan solusi dari permasalahan mitra meliputi tahap persiapan dan tahap pelaksanaan.

\section{Persiapan}

Tim Pelaksana Pengabdian Kemitraan Masyarakat (PKM) Kelompok ternak sapi potong di Desa Tanjungrejo Kecamatan Wuluhan, Kabupaten Jember STIE Mandala telah beberapa kali melakukan survei dan kunjungan ke mitra PKM. Kunjungan pertama dilakukan dengan mendekati ketua kelompok. Selanjutnya, kunjungan kedua dan ketiga dilakukan dengan mengadakan pertemuan kepada seluruh anggota kelompok. Hal ini penting karena ketua dan anggota dari dua kelompok ini (Mitra PKM) ini yang nanti diharapkan mampu melaksanakan dan mengadopsi alih teknologi tepat guna (TTG) ini. Hasilnya, Tim Pelaksana PKM dan kelompok mitra telah menyetujui beberapa permasalahan yang hendak diselesaikan dalam kegiatan PKM ini.

Tim Pelaksana PKM telah melakukan pertemuan kembali dengan mitra PKM untuk mendiskusikan jadwal kerja (yang lebih operasional) yang akan dilakukan. Hal ini penting agar kegiatan PKM ini tidak mengganggu kegiatan mereka sebagai peternak dan petani. Juga untuk menyelaraskan dengan kegiatan-kegiatan yang lain dari Tim Pelaksana PKM.

\section{Pelaksanaan}

Selanjutnya, metode pelaksanaan terdiri dari penyuluhan dan praktek, pendampingan dan pembinaan, penguatan modal, serta monitoring dan evaluasi.

a. Penyuluhan dan Praktek. Kegiatan penyuluhan dan praktek ini dilakukan untuk meningkatkan pengetahuan dan keterampilan kelompok mitra. Tentu saja 
kegiatan ini lebih mengedepankan aspek praktek daripada teori, yakni melalui konsep learning by doing. Penyuluhan dan praktek yang diberikan berisi tentang:

(1). mengatasi kekurangan hijauan dengan menanam rumput, terutama rumput gajah.

(2). mengatasi kekurangan hijauan dengan fermentasi jerami.

(3). membuat pakan konsentrat.

Penyuluhan dan praktek ini selain dilakukan oleh Tim Pelaksana PKM, dibantu oleh narasumber yang kompeten/ahli di bidang peternakan sapi potong.

b. Pendampingan dan Pembinaan. Kegiatan ini berupa kunjungan dan pembinaan Tim Pelaksana PKM kepada kelompok mitra mengenai usaha untuk mengoptimalkan usaha ternak sapi potongnya, sekaligus pemasarannya.

c. Penguatan modal. Diberikan bantuan dalam bentuk sharing kepada kelompok mitra, berdasarkan hasil kesepakatan, yakni berupa: Mesin Pencacah Rumput.

d. Monitoring dan Evaluasi. Monitoring dilakukan secara periodik untuk memantau capaian kegiatan PKM.

\section{Metode Pendekatan untuk Menyelesaikan Permasalahan Mitra}

Sejalan dengan penjelasan di atas, maka metode pendekatan yang ditawarkan adalah:

1. Metode Pendekatan Personal.

a. Mendekati ketua kelompok terlebih dahulu, baru kemudian ke anggotaanggotanya.

b. Mengundang dan mendiskusikan dalam sebuah pertemuan tentang permasalahan yang dihadapi dan solusinya, termasuk sharing alat dan mesin.

2. Metode Pendekatan Penyuluhan, di mana narasumber memberikan ceramah dan tanya jawab berkaitan dengan materi yang diberikan.

3. Metode Pendekatan Praktek, di mana seluruh anggota kelompok dibimbing dan dilibatkan dalam praktek.

4. Metode Pendampingan dan Pembinaan. Kegiatan ini berupa kunjungan dan pembinaan Tim Pelaksana PKM kepada kelompok mitra mengenai usaha untuk mengoptimalkan usaha ternak sapi potongnya, sekaligus pemasarannya. 


\section{HASIL DAN LUARAN YANG DICAPAI}

Usaha ternak sapi potong di Desa Tanjung Rejo, Kecamatan Wuluhan, Kabupaten Jember sebagian besar masih merupakan usaha peternakan rakyat yang dipelihara secara tradisional. Sebagian peternak memiliki sapi sendiri, sedangkan sebagian yang lain memelihara sapi milik orang lain dengan sistem bagi hasil, yang sering dinamakan "nggaduh". Setelah memelihara beberapa lama (4 - 6 bulan), sapi dijual dan hasilnya dibagi dua.

Usahat ternak sapi potong ada yang bersifat komersial dan ada yang bersifat semi komersial. Peternak yang berorientasi komersial, menghitung seluruh investasi termasuk seluruh biaya yang dikeluarkannya dibandingkan dengan pendapatan dari penjualan sapinya. Sedangkan peternak yang semi-komersial menjadikan sapi ternaknya sebagai tabungan jika sewaktu-waktu butuh uang dalam jumlah yang cukup besar.

Tim Pelaksana PKM telah beberapa kali melakukan kunjungan lanjutan dalam rangka menggali informasi dan observasi. Juga dalm rangka melakukan pendekatan kepada ketua kelompok ternak sapi potong di Desa Sumberejo Kecamatan Ambulu Kabupaten Jember. Berdasarkan kesepakatan, telah diadakan beberapa penyuluhan dan atau pendampingan tentang ketersediaan pakan, yaitu:

1. Penyuluhan dan praktek mengatasi kekurangan hijauan dengan menanam rumput, terutama rumput gajah,

2. Penyuluhan dan praktek pembuatan fermentasi jerami yang berfungsi mengganti pakan hijauan,

3. Penyuluhan dan praktek pembuatan pakan konsentrat.

Penyuluhan dan atau praktek dilakukan dan dibantu oleh pakar yang ahli di bidang peternakan.

Pakan merupakan biaya produksi yang terbesar dalam usaha peternakan yaitu sekitar $60-70 \%$ dari biaya produksi. Sehingga penyusunan ransum sapi tidak hanya harus mencukupi kebutuhan nutrisi tetapi juga harus secara ekonomis menguntungkan. Oleh karena itu, dalam penyusunan komposisi pakan didasarkan pada ketersediaan bahan dan harga yang murah tetapi tetap masih memiliki nilai gizi yang tinggi.

Untuk memastikan bahwa pelaksanaan aspek produksi pembuatan pakan (baik dengan menggunakan bahan baku hijauan, fermentasi jerami maupun konsentrat) telah dilakukan dengan benar, maka dilakukan kegiatan pendampingan. Pendampingan yang 
dimaksud adalah pendampingan secara berkelanjutan. Untuk memudahkan pendampingan, Tim Pelaksana PKM dibantu oleh para ketua kelompok. Pendampingan ini dimaksudkan agar mitra PKM berhasil dalam pelaksanaan kegiatan usaha ternak sapi potongnya, khususnya dalam pembuatan pakan untuk menjaga ketersediaan pakan secara berkelanjutan.

\section{KESIMPULAN}

Dari hasil kegiatan PKM yang berkaitan dengan ketersediaan pakan dapat disimpulkan beberapa hal, yaitu:

1. Peternak mampu memanfaatkan di sela-sela pekarangan/sawah yang dimiliki dengan menanam rumput terutama rumput gajah,

2. Peternak mampu membuat fermentasi jerami untuk mengganti pakan hijauan,

3. Peternak mampu membuat pakan konsentrat dengan menggunakan bahan baku yang ada di sekitar mereka dengan penambahan probiotik, untuk menghasilkan pakan ternak berkualitas tinggi

\section{UCAPAN TERIMA KASIH}

Terima kasih yang sebesar-besarnya kepada DRPM KEMENRISTEK DIKTI yang telah membiayai hibah PKM Tahun 2018 yang berjudul: "PKM KELOMPOK TERNAK SAPI POTONG DI DESA TANJUNG REJO, KECAMATAN WULUHAN, KABUPATEN JEMBER, PROVINSI JAWA TIMUR”

\section{DAFTAR PUSTAKA}

BPS. 2017. Kabupaten Jember Dalam Angka Tahun 2015. Kerja Sama: Badan Perencanaan Pembangunan Kabupaten Pemerintah Kabupaten Jember dengan Badan Pusat Statistik Kabupaten Jember.

Budiharjo, dkk. 2011. Analisis Profitabilitas Usaha Penggemukan Sapi Potong Di Kecamatan Gunungpati Kota Semarang. Jurnal Mediagro Vol. 7 No. 1. publikasiilmiah.unwahas.ac.id/index.php/Mediagro/article/.../685. Diakses 03 Juni 2017.

Koestanty, E., Paramita, L., dan Arimbi. 2014. IbM Kelompok Ternak Sapi Potong Dan Kelompok Tani Kedelai Kabupaten Lamongan Dalam Pemenuhan Swasembada Daging, Jurnal Agroveteriner Vol. 3 No. 1 Desember 2014. journal.unair.ac.id/download-fullpapers-agrovet76ddf26 de3full.doc. Diakses 10 Juni 2017. 
Sudarmono, AS dan Bambang. 2016. Panduan Beternak Sapi Potong. Penebar Swadaya. Jakarta.

Sudarmono, AS dan Sugeng, YB. 2008. Sapi Potong: Pemeliharaan, Perbaikan Produksi, Prospek Bisnis, Analisis Penggemukan. Penerbit Penebar Swadaya. Jakarta.

Suryana. 2009. Pengembangan Usaha Ternak Sapi Potong Berorientasi Agribisnis dengan Pola Kemitraan. Jurnal Litbang Pertanian 28 (1). http:// pustaka.litbang.pertanian.go.id/publikasi/p3281095.pdf. Diakses 06 Juni 2017.

Suwignyo, dkk. 2016. Penggunaan Fermentasi Pakan Komplet Berbasis Hijauan Pakan dan Jerami untuk Pakan Ruminansia. Indonesian Journal of Community $\begin{array}{lllllll}\text { Engagement } & \text { Vol. } & 1 & \text { No. } & 2 & \text { Maret } & 2016 .\end{array}$ http://download.portalgaruda.org/article.php?article $=406813 \& v a l=8860 \&$ title $=\mathrm{PE}$ NGGUNAAN\%20FERMENTASI\%20PAKAN\%20KOMPLET\%20BERBASIS\% 20HIJAUAN\%20PAKAN\%20DAN\%20JERAMI\%20UNTUK\%20PAKAN\%20R UMINANSIA. Diakses 06 Juni 2017.

Widiyaningrum, P. 2005. Motivasi Keikutsertaan Peternak Sapi Potong pada Sistem Kandang Komunal (Studi Kasus di Kabupaten Bantul Yogyakarta). http://www.akademik.unsri.ac.id/download/journal/files/udejournal/priyantini\%20 080302005.pdf. Diakses 03 Juni 2017. 